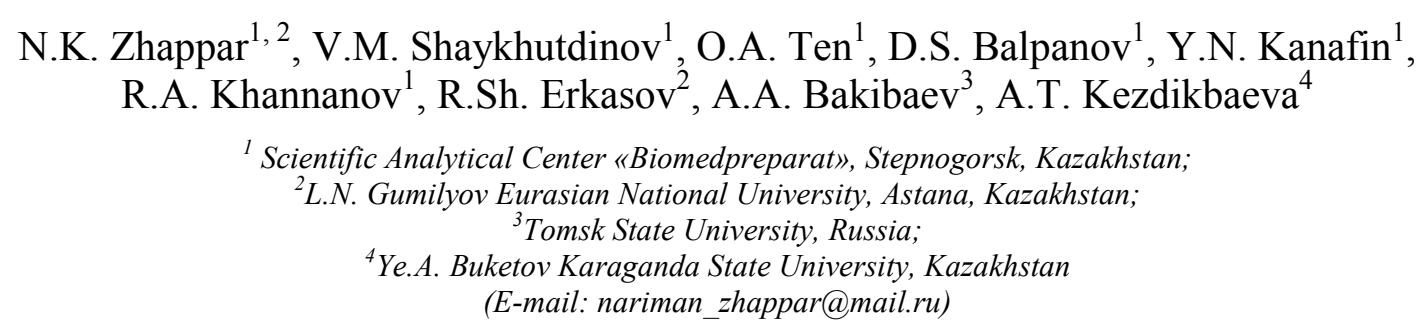

\title{
Destruction of cyanide and thiocyanate ions by bacterial and chemical methods
}

\begin{abstract}
This article deals with the destruction of cyanide and thiocyanate ions by bacterial and chemical methods. Adsorption with granulated activated carbon and oxidation with sodium pyrosulfite in the presence of a copper sulfate catalyst were used as methods of chemical destruction. The bacterial method of destruction was carried out using the bacterial consortium Agrobacterium tumefaciens AC-1, Agrobacterium tumefaciens AC-2 and Pseudomonas sp. AC-3. The control solutions were placed under identical conditions without the addition of any reagent. Sodium pyrosulfite was effective reagent at removing cyanide ions with $97 \%$ efficiency in 1-1.5 hours, while the bacterial consortiumwas the most productive against thiocyanate ions, resulting $99 \%$ removal at 120 hours. Thus, the significant amount of cyanide ions has been removed chemically in the first stage, to reduce the effect of high cyanide concentrations on the bacterial process. In the second stage, the cyanide ions have been removed until the MPC levels. In addition, thiocyanate ions were neutralized completely. Model experiments with technological solutions from the gold mining plant were carried out. According to the results of the studies, the respective degrees of bacterial destruction of CN- and SCNare $99 \%$ and $99.9 \%$. The residual concentration of $\mathrm{CN}$ - and SCN-ions in the treated solution was $\leq 0.1 \mathrm{mg} / \mathrm{l}$ and $\leq 4 \mathrm{mg} / \mathrm{l}$, respectively. These amounts correspond to the maximum permissible concentrations approved in the Republic of Kazakhstan and CIS countries.
\end{abstract}

Keywords: cyanide, thiocyanate, destruction, removal efficiency, degradation, sodium pyrosulfite, granulated activated carbon, bacterial consortium.

\section{Introduction}

Environmental protection has a big priority not only in the Republic of Kazakhstan, but also at international level. One of the biggest sources of contamination of the environment is a waste from the mining and processing industries. Disposal of cyanide- and thiocyanate containing residues after manufacturing is a big concern for the current waste management companies worldwide [1].

There are sufficient number of techniques for the treatment of waste water with the high content of cyanide- and thiocyanate ions, mainly, they are chemical approaches like hydrogen peroxide treatment [2], adsorption with activated carbon [3], alkaline chlorination [4], iron sulfide and zinc sulfate treatment, ozonation, UV and electrochemical neutralization $[5,6]$. Most of them showed an ability to remove cyanide from the liquid phase, but with low efficiency. In addition to the high cost, they might cause secondary toxic compounds.

\section{Methods}

Quantitative accounting of microorganisms was carried out with the use of methods of serial dilutions [7], Goryaev's counting chamber and «Zeiss Standart 25» microscope with phase contrast device [8]. The $\mathrm{pH}$ and redox potential (Eh) were determined through the use of universal analyzer «Mettler Toledo Seven Multi S47-K».Thiocyanate concentrations were determined photometrically with appropriate complex [9], while the determination of cyanides was conducted use of photometry with pyridine and barbituric acid [10] and by titration with silver nitrate [11]. The determination of the metal concentration was carried out using the Kvant-2AT atomic absorption spectrometer with atomization in a graphite furnace [11].

\section{Results}

High concentrations of cyanide and thiocyanate ions are commonly observed in industrial water after cyanide leaching of gold-containing sulfide ores or concentrates. The formation of thiocyanate occurs during gold cyanidation as a product of the reaction between cyanide ions and sulfur compounds (including elemental sulfur) [12]:

$$
\mathrm{S}^{0}+\mathrm{CN}^{-} \rightarrow \mathrm{SCN}^{-}
$$




$$
\begin{gathered}
\mathrm{S}^{2-}+\mathrm{CN}^{-}+\mathrm{H}_{2} \mathrm{O}+\mathrm{S} \rightarrow \mathrm{SCN}^{-}+2 \mathrm{OH}^{-} \\
\mathrm{S}_{2} \mathrm{O}_{3}{ }^{2-}+\mathrm{CN}^{-} \rightarrow \mathrm{SO}_{3}{ }^{2-}+\mathrm{SCN}^{-}
\end{gathered}
$$

Depending on the sulfur content and the number of turnover cycles, the concentration of thiocyanates in sewage or circulating waters can range from several milligrams to several grams per liter. Various model solutions containing $\mathrm{CN}^{-}$ions with a concentration of $300 \mathrm{mg} / 1$ and $\mathrm{SCN}^{-}$ions of $2500 \mathrm{mg} / 1$ were prepared for experiments. Adsorption with activated carbon and oxidation with sodium pyrosulfite in the presence of a copper sulfate catalyst were used as the methods of chemical destruction. The bacterial method of destruction was carried out by a consortium of bacteria Agrobacterium tumefaciens AC-1, Agrobacterium tumefaciens AC-2, Pseudomonas sp. AC-3. As a control in the above experiments, the control solution was prepared under identical conditions without adding any reagents.

Granular activated carbon (GAC) with a particle size of 2-4 mm and a density of $0.4 \mathrm{~g} / \mathrm{ml}$ was used as an adsorbent. Chemical treatment of cyanide and thiocyanate was carried out with sodium pyrosulfite in an amount of $5 \mathrm{~g} / \mathrm{g}$ for $\mathrm{CN}^{-}$and $7 \mathrm{~g} / \mathrm{g}$ for $\mathrm{SCN}^{-}$in the presence of a copper sulfate catalyst at $\mathrm{pH} 9.0-10.0$.

Bacterial degradation was carried out by a consortium of bacteria at temperature $30^{\circ} \mathrm{C} . \mathrm{pH}$ of the medium was maintained with a solution of sodium hydroxide at a level of 9.0-9.5. The experiments were carried out on an orbital shaker at $200 \mathrm{rpm}$. The results of the experiments are shown in Table 1 and Figures 1, 2.

Ta b l e 1

The results on the effectiveness of using chemical and bacterial methods at cyanide and thiocyanate ions removing

\begin{tabular}{|c|c|c|c|c|c|c|c|c|c|}
\hline \multirow{2}{*}{ Characteristics } & \multirow{2}{*}{$\begin{array}{c}\text { Duration, } \\
\text { hours }\end{array}$} & \multicolumn{2}{|c|}{ Control } & \multicolumn{2}{c|}{$\begin{array}{c}\text { Bacterial } \\
\text { consortium }\end{array}$} & \multicolumn{2}{|c|}{$\mathrm{GAC}$} & \multicolumn{2}{|c|}{$\mathrm{Na}_{2} \mathrm{~S}_{2} \mathrm{O}_{5}$} \\
\cline { 2 - 10 } & & $\mathrm{CN}^{-}$ & $\mathrm{SCN}^{-}$ & $\mathrm{CN}^{-}$ & $\mathrm{SCN}^{-}$ & $\mathrm{CN}^{-}$ & $\mathrm{SCN}^{-}$ & $\mathrm{CN}^{-}$ & $\mathrm{SCN}^{-}$ \\
\hline $\mathrm{C}_{\text {ini, }}, \mathrm{mg} / \mathrm{l}$ & 0 & 300 & 2500 & 300 & 2500 & 300 & 2500 & 300 & 2500 \\
\hline \multirow{5}{*}{$\mathrm{C}_{\text {res }}, \mathrm{mg} / \mathrm{l}$} & 12 & 279 & 2488 & 240 & 2188 & 171 & 2075 & 24 & 2463 \\
\cline { 2 - 11 } & 24 & 270 & 2481 & 225 & 1750 & 69 & 1925 & 18 & 2450 \\
\cline { 2 - 11 } & 36 & 262,5 & 2475 & 150 & 1563 & 45 & 1800 & 15 & 2433 \\
\cline { 2 - 10 } & 48 & 247,5 & 2469 & 112,5 & 1250 & 30 & 1700 & 15 & 2395 \\
\cline { 2 - 10 } & 96 & 217,5 & 2444 & 57 & 125 & 24 & 1300 & 12 & 2305 \\
\cline { 2 - 11 } & 120 & 202,5 & 2425 & 57 & 25 & 24 & 1200 & 9 & 2275 \\
\hline The removal efficiency, \% & & 32,5 & 3 & 81 & 99 & 92 & 52 & 97 & 9 \\
\hline
\end{tabular}

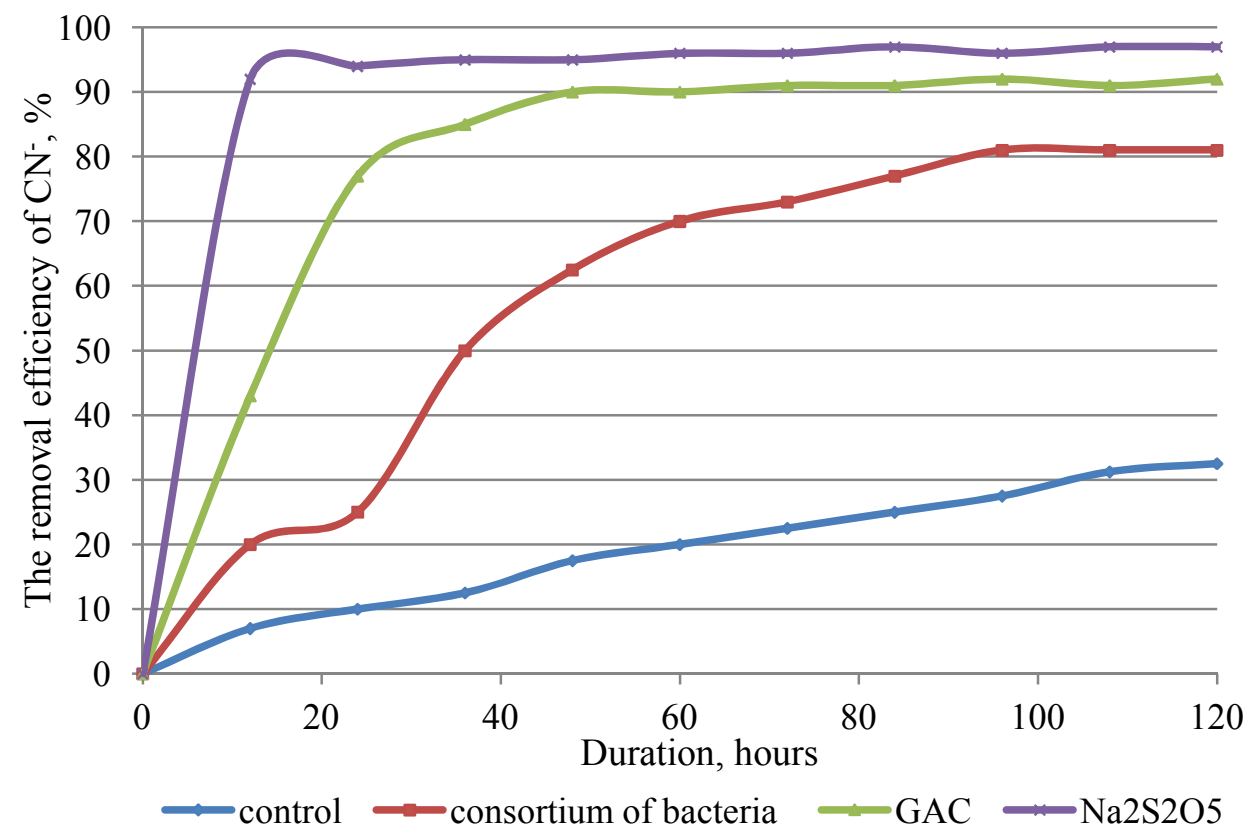

Figure 1. The removal efficiency of cyanides with chemical and bacterial methods 
Table 1 and Figure 1 shows that the most effective removal of cyanide ions has been observed when $\mathrm{Na}_{2} \mathrm{~S}_{2} \mathrm{O}_{5}$ was used. The removal of $\mathrm{CN}^{-}$was $97 \%$ in 1-1.5 hours. When the granular activated carbon was used, the removal of cyanide ions was also intensive and achieved $90 \%$ in 46 hours, while destruction occurred slower with the use of bacterial consortium, achieving $81 \%$ in 96 hours. Probably, this result is related to the inhibition of bacterial growth due to the increased concentration of cyanide ions [13].

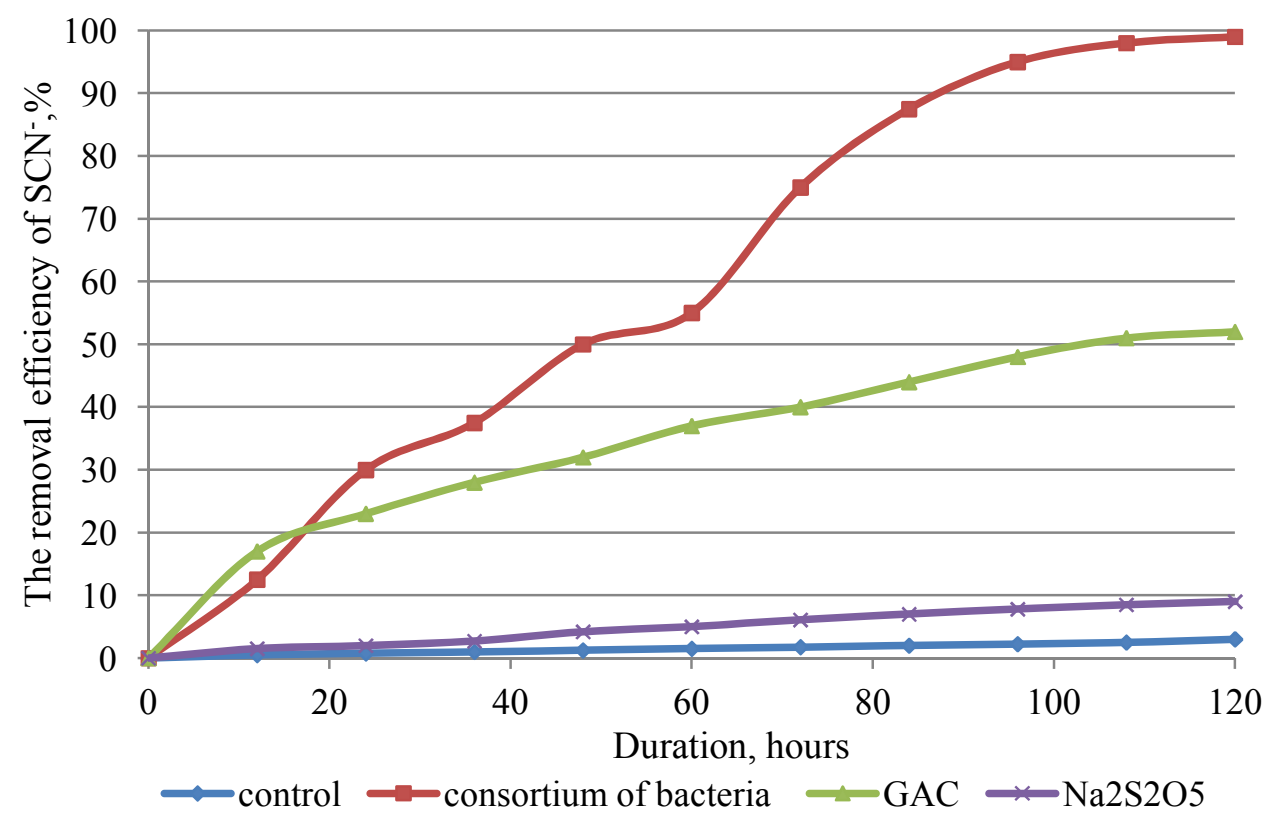

Figure 2. The effectiveness of chemical and bacterial methods at thiocyanate removal

The consortium of bacteria was able to remove $99 \%$ of the thiocyanate ions in 120 hours, showing the highest efficiency. However, other reagents have shown less activity at the same time with $52 \%$ and $9 \%$ for GAC and $\mathrm{Na}_{2} \mathrm{~S}_{2} \mathrm{O}_{5}$, respectively. In the control solutions, the decrease in the concentration of cyanide and thiocyanate ions occurred under the influence of atmospheric oxygen (Table 1 and Fig. 2).

Thus, sodium pyrosulfite was the most efficient reagent at removing cyanide ions with $97 \%$ efficiency in 1-1.5 hours, while bacterial consortium was the most productive against thiocyanate ions, resulting $99 \%$ removal at 120 hours.

In this regard, a two-stage combined technology for the removal of cyanide and thiocyanate was developed. At the first stage, In order to reduce the effect of high concentrations of cyanide on the bacterial process, a significant amount of cyanide ions is removed chemically. The second stage is the removal of the cyanide ions until the MPC levels, also full neutralization of the thiocyanate ions.

The results of previous experiments have shown that the most optimal method is combining of the chemical (sodium pyrosulfite treatment) and bacterial methods. In other words, conversion of the cyanides to the less toxic thiocyanates with subsequent bacterial degradation is a solution to the problem of wastewater treatment.

Samples of technological solutions from the Aksu gold extraction plant (Aqmola region, Kazakhstan) were selected for model experiments. The mineral ores and concentrates of the plant are treated with cyanide solutions. Table 2 shows the chemical analysis of the samples taken.

Table 2

The results of general chemical analysis of the solution from the Aksu gold extraction plant

\begin{tabular}{|l|c|c|c|c|c|c|c|c|c|}
\hline \multirow{2}{*}{\multicolumn{1}{|c|}{ Sample }} & \multicolumn{10}{|c|}{ Analyte } \\
\cline { 2 - 10 } & $\mathrm{CN}^{-}$ & $\mathrm{SCN}^{-}$ & $\mathrm{Cu}$ & $\mathrm{Fe}$ & $\mathrm{Zn}$ & $\mathrm{Mg}$ & $\mathrm{As}$ & $\mathrm{Ni}$ & $\mathrm{Sb}$ \\
\hline $\begin{array}{l}\text { Industrial } \\
\text { solution, } \mathrm{mg} / \mathrm{l}\end{array}$ & 221 & 3570 & 15 & 730 & 7 & 2 & 1,7 & 3 & 3 \\
\hline
\end{tabular}


In the first stage, cyanides and metal cyanide complexes were oxidized with sodium pyrosulfite $(5 \mathrm{~g} / \mathrm{g})$, in the presence of copper ions at $\mathrm{pH} 9.0-10.0$.

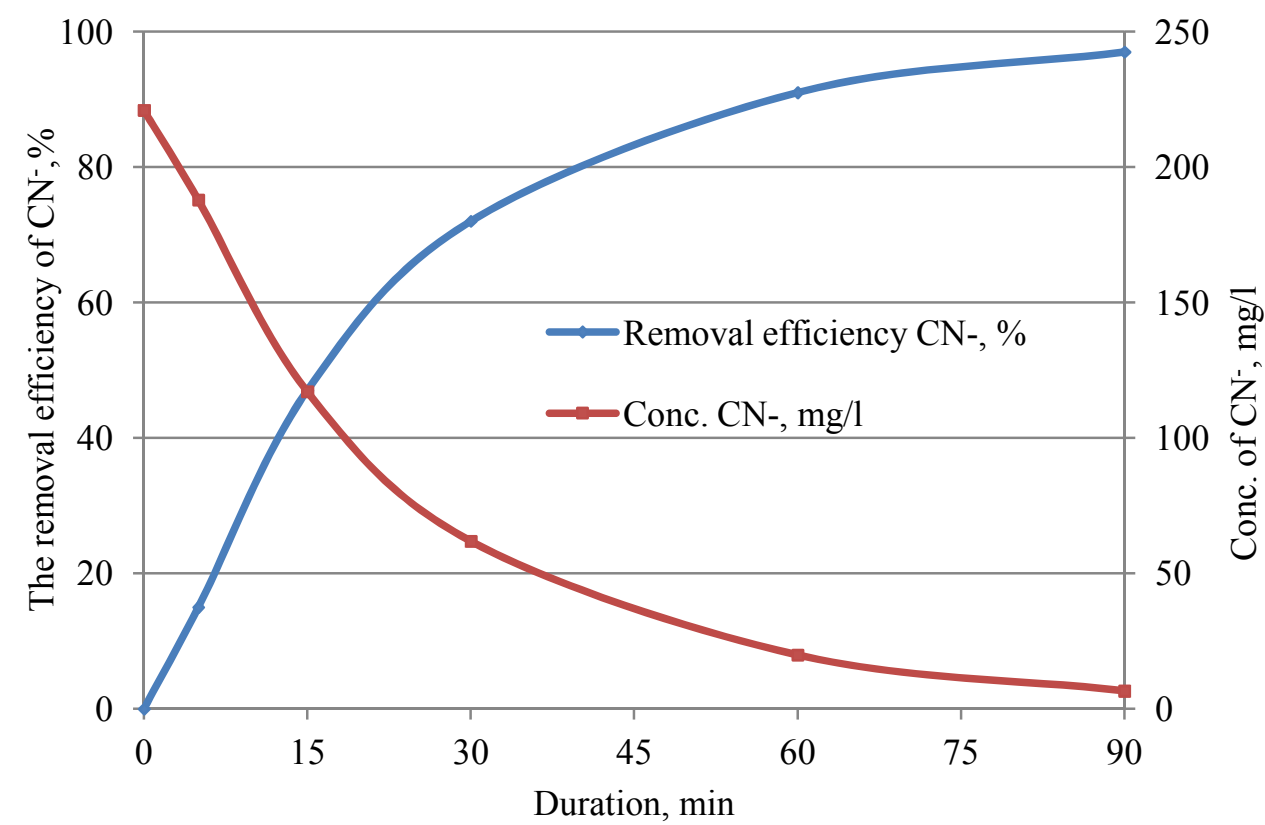

Figure 3. Effectiveness of $\mathrm{CN}^{-}$removal with sodium pyrosulfite

The obtained data (Fig. 3) show that the neutralization degree is $97 \%$ in 90 minutes, the residual $\mathrm{CN}^{-}$ concentration was $6.6 \mathrm{mg} / \mathrm{l}$, whereas the concentration of thiocyanate ions increased due to the oxidation of cyanide ions, which amounted to $3785 \mathrm{mg} / 1$.

In the second stage, the processing solution was passed through a bioreactor for destruction of the residual content of cyanide and thiocyanate by bacterial consortium immobilized on a zeolite. The results of the experiments are shown in Figures 4, 5.

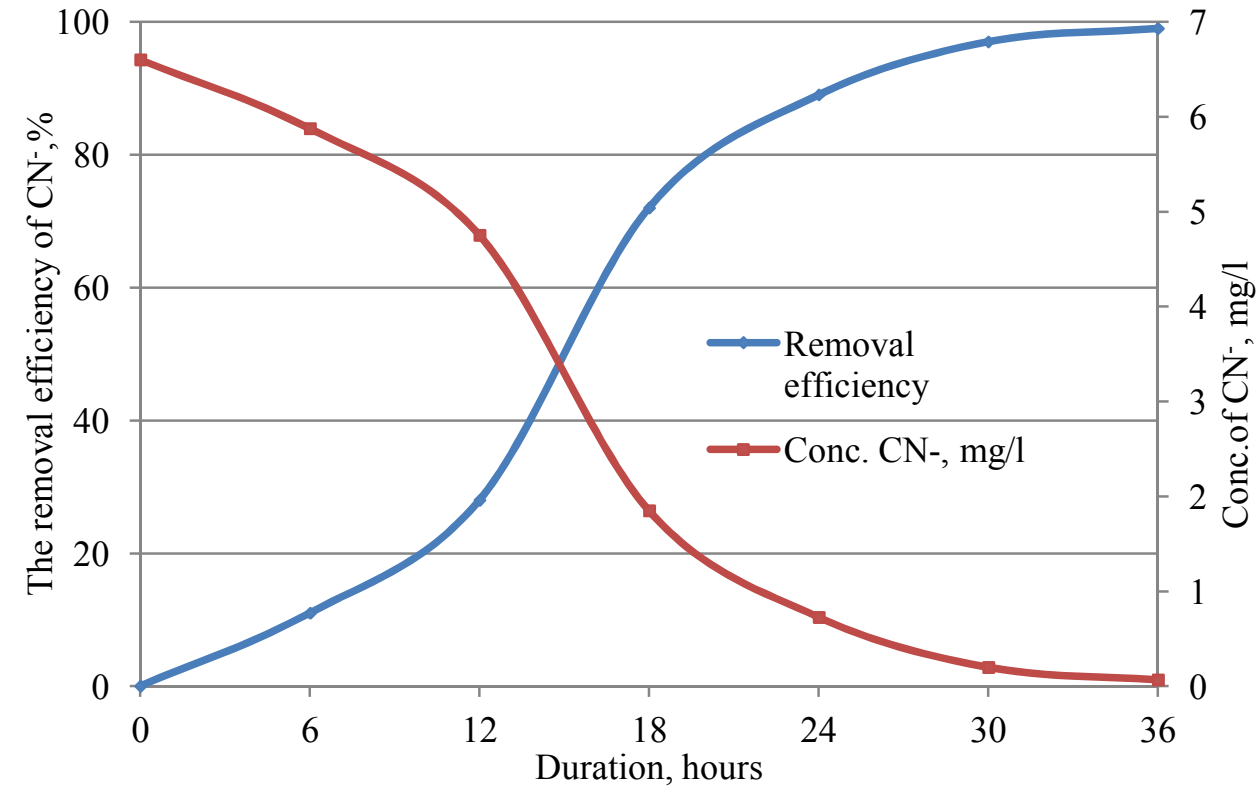

Figure 4. Effectiveness of $\mathrm{CN}^{-}$removal with bacterial consortium Agrobacterium tumefaciensAC-1, Agrobacterium tumefaciensAC-2, Pseudomonas sp. AC-3 


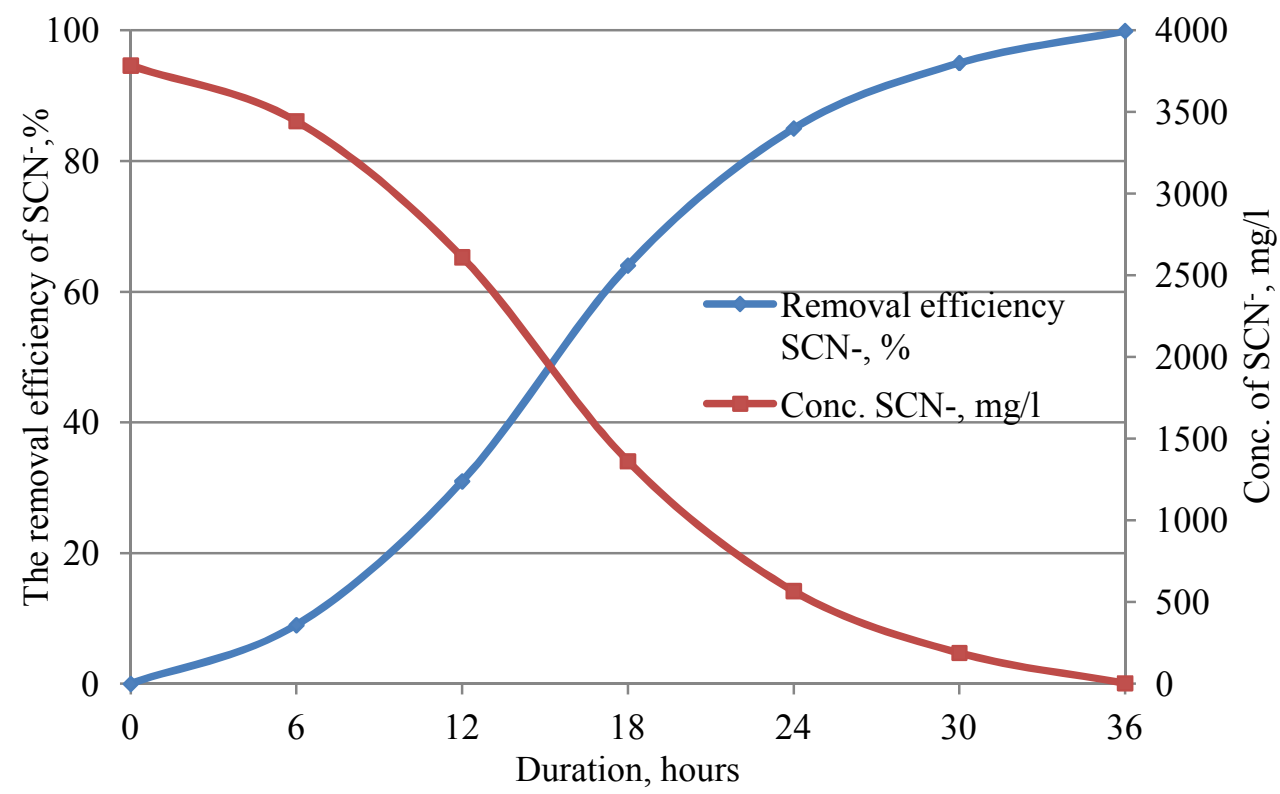

Figure 5. Effectiveness of $\mathrm{SCN}^{-}$removal with bacterial consortium Agrobacterium tumefaciens AC-1, Agrobacterium tumefaciensAC-2, Pseudomonas sp. AC-3

Based on the results of the experiments, the degree of bacterial destruction of $\mathrm{CN}^{-}$and SCNare $99 \%$ and $99.9 \%$, respectively. Moreover, respective residual concentrations of $\mathrm{CN}^{-}$and $\mathrm{SCN}$-ions in the treated solution were $\leq 0.1 \mathrm{mg} / 1$ and $\leq 4 \mathrm{mg} / 1$, which corresponds to the maximum permissible concentrations approved in the Republic of Kazakhstan and CIS countries.

\section{References}

1 Rajesh R.D. Cyanide in industrial wastewaters and its removal: A review on biotreatment / R.D. Rajesh, G. Abhinav, B. Chandrajit // Journal of Hazardous Materials. — 2009. — Vol. 163. - P. 1-11.

2 Kitis M. Heterogeneous catalytic degradation of cyanide using copper-impregnated pumice and hydrogen peroxide / M. Kitis, E. Karakaya, N.O. Yigit, G. Civelekoglu, A. Akcil // Water Research. - 2005. - Vol. 39. - P. 1652-1662.

3 Depci T. Apricot stone activated carbons adsorption of cyanide as revealed from computational chemistry analysis and experimental study / T. Depci, Y. Onal, K.A. Prisbrey // Journal of the Taiwan Institute of Chemical Engineers. — 2014. — Vol. 45, Iss. 5. - P.2511-2517.

4 Lu. J. Anodic behaviour of alkaline solutions containing copper cyanide and sulfite on the graphite anode / J. Lu, D.B. Dreisinger, W.C. Cooper // Journal of Applied Electrochemistry. — 2002. — Iss. 32. — P. 1109-1118.

5 Botz M.M. Cyanide Treatment: Physical, Chemical, and Biological Processes / M.M. Botz, T.I. Mudder, A.U. Akcil // Gold Ore Processing (Second Edition). — 2016. - P. 619-645.

6 Hanela S. Removal of iron-cyanide complexes from wastewaters by combined UV-ozone and modified zeolite treatment / S. Hanela, J. Durán, S. Jacobo // Journal of Environmental Chemical Engineering. — 2015. — Vol. 3, Iss. 3. — P. $1794-1801$.

7 Методы общей бактериологии: [в 3 т.] Т. 2 / Под ред. Ф. Герхардт. — М.: Мир, 1984. — С. 450-454.

8 Clayton R.A. Intraspecific variation in small-subunit rRNA sequences in GenBank: why single sequences may not adequately represent prokaryotic taxa / R.A. Clayton, G. Sutton, P.S. Hinkle, Jr. C. Bult, C. Fields // International Journal of Systematic Bacteriology. - 1995. - Vol. 45. - P. 595-599.

9 Zhang Q. Pseudoepidemic due to a unique strain of Mycobacterium szulqai: genotypic, phenotypic, and epidemiological analysis / Q. Zhang, R. Kennon, M.A. Koza, K. Hulten, J.E. Clarridge // Journal of Clinical Microbiology. — 2002. — Vol. 40. — P. 1134-1139.

10 Clarridge J.E. Impact of 16S rRNA Gene Sequence Analysis for Identification of Bacteria on Clinical Microbiology and Infectious Diseases / J.E. Clarridge // Clinical Microbiology Reviews. — 2004. — Vol. 17. — P. 840-862.

11 Vogel A.I. Vodel's textbook of quantitative chemical analysis: textbook / A.I. Vogel. — London: Longman Group UK Limited, 1989. - P. 690.

12 Масленицкий И.Н. Металлургия благородных металлов: учебник для вузов / И.Н. Масленицкий, Л.В. Чугаев, В.Ф. Борбат. - М.: Металлургия, 1987. - 432 с.

13 Adams D.J. Biological cyanide degradation / D.J Adams, J.V. Komen, T.M. Pickett // Young, C. (Ed.), Cyanide: Social, Industrial and Economic Aspects. The Metal Society, United States. — 2001. - P. 203-213. 
Н.К. Жаппар, В.М. Шайхутдинов, О.А. Тен, Д.С. Балпанов, Е.Н. Канафин, Р.А. Ханнанов, Р.Ш. Еркасов, А.А. Бакибаев, А.Т. Кездикбаева

\title{
Бактериялық-химиялы тәсілмен цианид- және тиоцианат-иондар деструкциясы
}

\begin{abstract}
Мақалада бактериялық және химиялық әдістермен цианид және тиоцианат-иондар деструкция мәселелері қарастырылған. Химиялық деструкция әдістері ретінде мыс сульфаты катализаторында натрий пиросульфатпен тотықтыру және белсендірілген көмірмен адсорбциялау қолданылды. Деструкцияның бактериялық тәсілі Agrobacterium tumefaciens AC-1, Agrobacterium tumefaciens AC-2 және Pseudomonassp AC-3 бактериялар консорциумымен жүргізілді. Тәжірибелерді қадағалау мақсатымен бірдей шарттарда реагент қосылуынсыз модельдік ерітінділер дайындалды. Цианид иондар алып шығару үшін ең тиімді тәсіл натрий пиросульфит ықпалында байқалды: 97 \% 1-1,5 сағ; Agrobacterium tumefaciens AC-1, Agrobacterium tumefaciens AC-2 және Pseudomonas sp. AC-3 бактериялар консорциумы тиоцианат-иондар алып шығару үшін: 120 сағ - 99 \%. Сонымен, бірінші кезеңде бактериялық процеске бөгет болуы мүмкін цианидтің жоғары концентрациясын химиялық әдіспен төмендетті. Екінші кезеңде цианид иондар ШРК деңгейіне дейін азайып, тиоцианатиондардың толық залалсыздандырылуы жүргізілді. Алтын шығару фабриканың технологиялық ерітінділерімен модельді эксперименттер жасалды. Зерттеу нәтижелері бойынша бактериялар консорциумымен $\mathrm{CN}^{-}$және $\mathrm{SCN}^{-}$бұзылу дәрежесі 99 және 99,9 \% сәйкес. Өңделген ерітіндідегі $\mathrm{CN}^{-}$ және $\mathrm{SCN}^{-}$-иондарының қалдық концентрациялары $\leq 0,1$ мг/л және $\leq 4$ мг/л сәйкес болды. Бұл Қазақстан Республикасы мен ТМД елдерінде қабылданған шекті рұқсат етілген концентрация ретінде қабылданған деңгейге сай келді.
\end{abstract}

Кілт сөздер: цианид, тиоцианат, деструкция, алып шығару тиімділігі, азу, натрий пиросульфиті, түйіршіктелген белсендірілген көмір, бактериялар консорциумы.

Н.К. Жаппар, В.М. Шайхутдинов, О.А. Тен, Д.С. Балпанов, Е.Н. Канафин, Р.А. Ханнанов, Р.Ш. Еркасов, А.А. Бакибаев, А.Т. Кездикбаева

\section{Деструкция цианид- и тиоцианат-ионов бактериально-химическим способом}

\begin{abstract}
В статье рассмотрены вопросы деструкции цианид- и тиоцианат-ионов бактериальными и химическими методами. В качестве методов химической деструкции были использованы адсорбция гранулированным активированным углем и окисление пиросульфитом натрия в присутствии катализатора сульфата меди. Бактериальный способ деструкции проведен консорциумом бактерий Agrobacterium tumefaciens AC-1, Agrobacterium tumefaciens AC-2 и Pseudomonassp. АC-3. Для контроля ставили модельные растворы при идентичных условиях без добавления какого-либо реагента. Наиболее эффективное удаление цианид-ионов наблюдалось при воздействии пиросульфитом натрия: 97 \% за 1-1,5 ч; для удаления тиоцианат-ионов консорциум бактерий Agrbacterium tumefaciens AC-1, Agrobacterium tumefaciens AC-2 и Pseudomonassp. AC-3: за 120 ч - 99 \%. Таким образом, на первой стадии удаляется значительное содержание цианид-ионов химическим способом для снижения воздействия высоких концентраций цианида на бактериальный процесс. На второй стадии происходит удаление цианидионов до ПДК, а также полное обезвреживание тиоцианат-ионов. Проведены модельные эксперименты с технологическими растворами золотоизвлекательной фабрики. По результатам исследований степень разрушения $\mathrm{CN}^{-}$и $\mathrm{SCN}^{-}$-ионов консорциумом бактерий составляет 99 и 99,9 \% соответственно. Остаточная концентрация $\mathrm{CN}^{-}$и $\mathrm{SCN}^{-}$-ионов в обработанном растворе составила $\leq 0,1$ мг/л и $\leq 4$ мг/л соответственно, что отвечает предельно допустимой концентрации утвержденных в Республике Казахстан и странах СНГ.
\end{abstract}

Ключевые слова: цианид, тиоцианат, деструкция, эффективность удаления, деградация веществ, пиросульфит натрия, гранулированный активированный уголь, консорциум бактерий.

\section{References}

1 Rajesh, R.D., Abhinav, G., \& Chandrajit, B. (2009). Cyanide in industrial wastewaters and its removal: A review on biotreatment. Journal of Hazardous Materials, 163, 1-11.

2 Kitis, M., Karakaya, E., Yigit, N.O., Civelekoglu, G., \& Akcil, A. (2005). Heterogeneous catalytic degradation of cyanide using copper-impregnated pumice and hydrogen peroxide. Water Research, 39, 1652-1662.

3 Depci, T., Onal, Y., \& Prisbrey, K.A. (2014). Apricot stone activated carbons adsorption of cyanide as revealed from computational chemistry analysis and experimental study. Journal of the Taiwan Institute of Chemical Engineers, 45(5), $2511-2517$.

4 Lu., J., Dreisinger, D.B., \& Cooper, W.C. (2002). Anodic behaviour of alkaline solutions containing copper cyanide and sulfite on the graphite anode. Journal of Applied Electrochemistry, 32, 1109-1118. 
5 Botz, M.M., Mudder, T.I., \& Akcil, A.U. (2016). Cyanide Treatment: Physical, Chemical, and Biological Processes. Gold Ore Processing, Second Edition, 619-645.

6 Hanela, S., Durán, J., \& Jacobo, S. (2015). Removal of iron-cyanide complexes from wastewaters by combined UV-ozone and modified zeolite treatment. Journal of Environmental Chemical Engineering, 3(3), 1794-1801.

7 Gerhardt, F. (Eds.) (1984). Metody obschei bakteriolohii [Methods of general bacteriology]. (Vols. 1-3; Vol. 2). Moscow: Mir [in Russian].

8 Clayton, R. A., Sutton, G., Hinkle, P. S., Bult, Jr. C., \& Fields, C. (1995). Intraspecific variation in small-subunit rRNA sequences in GenBank: why single sequences may not adequately represent prokaryotic taxa. International Journal of Systematic Bacteriology, 45, 595-599.

9 Zhang, Q., Kennon, R., Koza, M. A., Hulten, K., \& Clarridge, J.E. (2002). Pseudoepidemic due to a unique strain of Mycobacterium szulqai: genotypic, phenotypic, and epidemiological analysis. Journal of Clinical Microbiology, 40, 1134-1139.

10 Clarridge, J.E. (2004). Impact of 16S rRNA Gene Sequence Analysis for Identification of Bacteria on Clinical Microbiology and Infectious Diseases. Clinical Microbiology Reviews, 17, 840-862.

11 Vogel, A.I. (1989). Vodel's textbook of quantitative chemical analysis. Longman Group UK Limited.

12 Maslenitsky, I.N., Chugayev, L.V., \& Borbat, V.F. (1987). Metallurhiia blahorodnykh metallov [Metallurgy of precious metals]. Moscow: Metallurhiia [in Russian].

13 Adams, D.J., Komen, J.V., \& Pickett, T.M. Biological cyanide degradation. (2001). In: C. Young (Ed.), Cyanide: Social, Industrial and Economic Aspects. The Metal Society, United States, 203-213. 